\title{
Biogeographical Evidence for the Grass (Poaceae) Species of Pleistocene Beringian Lowlands
}

\author{
DAVID K. SWANSON ${ }^{1}$
}

(Received 13 May 2005; accepted in revised form 3 October 2005)

\begin{abstract}
Late Pleistocene Beringia had herb-dominated vegetation with abundant grasses (Poaceae), and it was inhabited by an impressive assemblage of large grazing mammals. This paper reconstructs the list of most probable late Pleistocene Beringian lowland grass species from biogeographical evidence. Late Pleistocene eolian sediments and buried soils indicate that large areas of the Beringian lowlands had nutrient-rich, silty soils that occurred over ice-rich permafrost but were generally not waterlogged. A list of likely grasses was compiled from all species that have been recorded on similar fine-grained, mesic-to-dry lowland soils (i.e., presumed refugia) and are distributed at least sporadically across the whole region today. Grasses from 13 genera met these criteria, including most of the taxa that have been identified as late Pleistocene fossils from the study area. Most of these grasses are high-latitude species of genera that are also common in temperate latitudes (e.g., Elymus, Festuca, and Poa). This diverse group of plants has a wide range of adaptations today, suggesting that grasses would have been available to occupy a variety of habitats through Pleistocene climatic fluctuations. Among these grasses are a number of highly productive forage species.
\end{abstract}

Key words: Alaska, Beringia, biogeography, grass, Pleistocene, Poaceae, Russia, tundra, steppe, vegetation

RÉSUMÉ. La végétation de la Béringie du Pléistocène supérieur était dominée par des herbes abondantes (Poaceae). De plus, elle était habitée par un assemblage impressionnant de gros mammifères broutards. Dans cet article, nous dressons la liste des espèces végétales des basses-terres les plus probables de la Béringie du Pléistocène supérieur à partir d'observations biogéographiques. Les sédiments éoliens du Pléistocène supérieur et les sols enfouis laissent supposer que de vastes régions des basses-terres de la Béringie avaient des sols limoneux riches en nutriments situés sur du pergélisol riche en glace, sans être généralement gorgés d'eau. La liste des herbes susceptibles de s'être retrouvées à l'époque a été compilée à partir de toutes les espèces qui ont été enregistrées sur des sols fins similaires de basses-terres allant de mésoïques à secs (i.e., refuges naturels présumés) et qui sont réparties, de manière tout au moins sporadique, dans toute la région aujourd'hui. Les herbes de 13 genres ont satisfait ces critères, ce qui comprend la plupart des taxons qui ont été identifiés à titre de fossiles du Pléistocène supérieur dans la région visée par l'étude. La plupart de ces herbes sont des espèces de genres se retrouvant en haute altitude qui sont également en latitudes tempérées (comme Elymus, Festuca et Poa). De nos jours, ce groupe de végétaux divers a subi de nombreuses adaptations, ce qui laisse supposer que les herbes auraient occupé une variété d'habitats pendant les fluctuations climatiques du Pléistocène. Parmi ces herbes, notons un certain nombre d'espèces fourragères hautement productives.

Mots clés : Alaska, Béringie, biogéographie, herbe, Pléistocène, Poaceae, Russie, toundra, steppe, végétation

Traduit pour la revue Arctic par Nicole Giguère.

РЕФЕРАТ. В позднеплейстоценовой Берингии преобладала травянистая растительность, важную роль в которой играли злаки (Роасеаe), тогда как здесь обитала богатая травоядная мегафуна. В статье на основе биогеографических данных составляется список вероятных позднеплейстоценовых злаков Берингиских равнин. Познеплейстоценовые эоловые отложения и погребённые почвы показывают, что на Берингийских равнинах господствовали богатые пылеватые почвы, хорошо аэруемые но подстилаемые льдистой мерзлотой. Наш список составлен изо всех видов, которые теперь распространяются по всему региону и отмечены на подобных равнинных почвах (т.е. на предполагаемых рефугиумах). Удовлетворяют эти критерии злаки из 13-и родов, в том числе большинство ископаемых познеплейстоценовых таксонов изученного региона. Большинство злаков является высокоширотные виды широко распространённых родов умеренных широт (Elymus, Festuca, Poa, и дp.). Эта разнообразная группа растений имеет большой диапазон приспособлений, которые способствовали их присутствие на разнообразных местообитаниях в течений плейстоценовых климатических колебаний. Среди них несколько известных высокопродуктивных кормовых видов.

Ключевые слова: Аляска, Берингия, биогеография, злак, плейстоцен, растительность, Россия, степь, тундра

${ }^{1}$ U.S. Forest Service, P.O. Box 907, Baker City, Oregon 97814, U.S.A.; dkswanson @ fs.fed.us

(C) The Arctic Institute of North America 


\section{INTRODUCTION}

The Pleistocene vegetation of Alaska and northeastern Asia has attracted the attention of researchers for decades, yet its composition remains enigmatic. Numerous pollen studies have shown that herbaceous species dominated the region through much of the late Pleistocene, and grasses (Poaceae) were more abundant in the region then than they are today (Colinvaux, 1967; Matthews, 1974; Tomirdiaro, 1980; Tomirdiaro and Chernenkiy, 1987; Lozhkin et al., 1993; Anderson and Brubaker, 1994; Bigelow et al., 2003). This vegetation has attracted particular interest because it supported an assemblage of large grazing mammals more diverse than today's, in spite of the severe ice-age climate (Guthrie, 1990). Unfortunately, grass pollen cannot be identified below the family level. Grass macrofossil evidence is fairly limited, with many specimens identified only to the genus level and locations concentrated in the continental western and eastern portions of Beringia (Table 1, Fig. 1). Pleistocene plant macrofossil collections from central Beringia (Elias et al., 1997; Goetchus and Birks, 2001) have not yet yielded identifiable grass macrofossils. Thus uncertainty remains about what species produced the Pleistocene grass pollen.

Meanwhile, our knowledge of the soils of the region, both during the Pleistocene and today, has reached the point that we can identify which environments could act as refugia for dominant Pleistocene plants. In this paper, I examine the grass flora of these potential refugia across the Beringian region to infer which species were likely to have inhabited the region during the Pleistocene.

\section{SOILS OF BERINGIAN LOWLANDS: THE PLEISTOCENE AND TODAY}

The soil environment of the Pleistocene Beringian lowlands is known from studies of ice-age soils buried under volcanic ash on the Seward Peninsula, Alaska, by Höfle and Ping (1996) and Höfle et al. (2000); from studies of buried soils in loess in Russia (Gubin, 1994) and the Yukon Territory (Sanborn et al., in press); and from studies of the frozen silty deposits of the region, which consist largely of buried soil material (Péwé, 1975; Tomirdiaro, 1980; Tomirdiaro and Chernenkiy, 1987; Fraser and Burn, 1997; Kotler and Burn, 2000; Schirrmeister et al., 2002; Gubin et al., 2003). These studies have revealed a soil environment that was quite uniform across the lowlands of the expansive, unglaciated region that extends from western Yukon and Alaska across the Bering Strait to the Lena Mountains in Russia (Fig. 1).

Large areas of soils formed in silty sediments, mainly loess or loess redeposited by slope processes, and in finegrained deposits of low-gradient rivers. Minerals were largely unweathered and retained the nutrients of their parent materials, which were calcareous in some places (resulting in slightly alkaline soils) and non-calcareous in others (resulting in near-neutral soils). The soils were rich in organic matter and fine roots: the loess deposits and the buried soils they include contain $1 \%$ to $10 \%$ organic carbon. The organic matter was rather high in nitrogen, with carbon-to-nitrogen ratios near 10 . Soils generally lacked a thick surface peat layer, but they were underlain by very ice-rich permafrost. Estimates of active-layer thicknesses include 32 to $64 \mathrm{~cm}$ at $17500{ }^{14} \mathrm{C}$ yr BP on the Seward Peninsula, Alaska (Höfle and Ping, 1996), and 65 to $85 \mathrm{~cm}$ at about $30000{ }^{14} \mathrm{C} \mathrm{yr} \mathrm{BP}$ in the Kolyma River region of Russia (Gubin et al., 2003). Similar fine-grained, ice-rich deposits covered much of the exposed continental shelves during the Pleistocene glacial periods (Romanovskii et al., 2004; Fig. 1).

The predominance of mineral soil (as opposed to peat) suggests that waterlogging was not widespread, just as we would expect from the presence of large hoofed mammals such as bison and horses, which are adapted to firm substrates (Guthrie, 1990). In short, these soils were probably optimal in terms of productivity for the environment in which they occurred: they were high in mineral nutrients and nitrogen, neither acidic nor highly alkaline or saline, well aerated, and (as evidenced by the ice-rich permafrost) had some excess moisture available at least seasonally.

In contrast, the dominant soils of lowlands in the region today are mostly waterlogged and have a surface peat layer that is typically acidic (Naumov, 2004; Ping et al., 2004). Tundra vegetation is dominated by sedges (Carex) and cotton sedge (Eriophorum), with forest in continental areas (CAVM Team, 2003). Transition to the present environment began about 14000 years ago and continued for many thousands of years with the asynchronous arrival of various plant species from the south (Anderson and Brubaker, 1994).

Soils that resemble in a general way those that dominated the region in the Pleistocene still occupy specialized habitats today. Fine-grained soils underlain by permafrost, but well-drained and lacking a thick peat layer, are scattered across silty lowlands of the study area on topographic convexities, such as high-center polygons, brows of short slopes leading down to incised streams or thermokarst depressions, and pingos (Tedrow and Hill, 1955; Everett and Parkinson, 1977). Broadly similar soils also occur on sand dunes (especially those with a silty or very fine sandy mantle) and on fresh silty or sandy alluvium (Everett, 1980). Modern soils on newly deposited, unweathered, or calcium-rich geologic materials have nearneutral soil $\mathrm{pH}$ similar to what probably prevailed in Pleistocene soils (Walker et al., 2001).

With the Bering Land Bridge in place, the silty lowlands were continuous across the entire region from the Yukon Territory across the Bering Strait through northeastern Asia (Fig. 1); thus, there were no major barriers to plant migration for species adapted to this environment. Some very widespread grass species may have occupied these lowlands, as the ubiquitous species Eriophorum vaginatum 
TABLE 1. Pleistocene grass genera and species recorded as macrofossils in the study area.

\begin{tabular}{|c|c|c|c|}
\hline Taxon & Age, thousand ${ }^{14} \mathrm{C}$ yr & Source & Location ${ }^{1}$ \\
\hline $\begin{array}{l}\text { Deschampsia } \\
\text { Elymus } \\
\text { cf. Festuca } \\
\text { Poa }\end{array}$ & $16-19$ & Zazula (2002), Zazula et al. (2003a). Silty alluvium, northern Yukon Territory & 1 \\
\hline $\begin{array}{l}\text { Deschampsia cespitosa } \\
\text { D. brevifolia } \\
\text { Elymus } \\
\text { Festuca } \\
\text { Hierochlö hirta ssp. arctica } \\
\text { Poa }\end{array}$ & 24 & Zazula et al. (2005). Rodent middens in loess, central Yukon Territory. & 2 \\
\hline $\begin{array}{l}\text { Elymus } \\
\text { Poa } \\
\text { Festuca }\end{array}$ & 26 & Zazula et al. (2003a, b). Alluvial peat deposit, central Yukon Territory. & 2 \\
\hline $\begin{array}{l}\text { Arctophila fulva } \\
\text { Bromus pumpellianus } \\
\text { Festuca altaica } \\
\text { F. lenensis } \\
\text { Hordeum brevisubulatum } \\
\text { Poa arctica } \\
\text { Poa attenuata } \\
\text { Poa botryoides } \\
\text { Puccinellia hauptiana }\end{array}$ & $28-32$ & Gubin et al. (2003). Rodent middens in loess, Russia (lower Kolyma River region) & 4 \\
\hline $\begin{array}{l}\text { Agropyron (sensu Hitchcock, } \\
\text { today's Elymus) } \\
\text { Danthonia }\end{array}$ & 36 & Guthrie (1990). Fragments on bison teeth, central Alaska & 3 \\
\hline $\begin{array}{l}\text { Calamagrostis } \\
\text { cf. Festuca } \\
\text { cf. Helictotrichon krylovii }\end{array}$ & $34-39$ & $\begin{array}{l}\text { Solonevich and Vikhireva-Vasilkova (1977). Stomach contents of the Selerikan } \\
\text { fossil horse, Russia (upper Indigirka River region). }\end{array}$ & 7 \\
\hline $\begin{array}{l}\text { Calamagrostis } \\
\text { Helictotrichon krylovii } \\
\text { Festuca }\end{array}$ & 42 & $\begin{array}{l}\text { Ukraintseva (1981). Stomach contents of the Shandrin mammoth, Russia (lower } \\
\text { Indigirka River region). }\end{array}$ & 6 \\
\hline $\begin{array}{l}\text { Agropyron cristatum } \\
\text { Alopecurus alpinus } \\
\text { Beckmannia eruciformis } \\
\text { Hordeum brevisubulatum }\end{array}$ & 44 & $\begin{array}{l}\text { Ukraintseva (1981). Stomach contents of the Berezovka mammoth, Russia (upper } \\
\text { Kolyma River region). }\end{array}$ & 5 \\
\hline $\begin{array}{l}\text { Agropyron (sensu Hitchcock, } \\
\text { today's Elymus) } \\
\text { Bromus } \\
\text { Poa }\end{array}$ & $?$ & Guthrie (1990). Fragments on 44 bison teeth, central Alaska. & 3 \\
\hline
\end{tabular}

${ }^{1}$ Numbers refer to locations in Figure 1.

L. and Carex aquatilis Wahlenb. occupy them today. The great change at the beginning of the Holocene would have restricted the dominant species of the Pleistocene to refugia - the common yet small and disjunct patches of unforested, mesic-to-dry soil described above. It is reasonable to assume that the species that dominated these soils in the Pleistocene persist today on these specialized sites, though in smaller numbers and in different assemblages. Thus, we may search for the dominant Pleistocene grassesthose that produced the enigmatic pollen records-among those species that are widespread on well-drained soils across the whole expanse of the Beringian silty lowlands. In contrast, grasses that are restricted to one side of the Bering Strait, and which grow only on inland sites known to have a climate warmer than what prevailed in the
Pleistocene, are less likely to have dominated the Pleistocene Beringian plains.

\section{METHODS}

I searched for grasses that meet two criteria: 1) their range extends at least sporadically across the lowlands in northeastern Asia and northwestern North America (Fig. 1), and 2) they have been reported on mesic-to-xeric, silty or sandy lowland soils. Both plant ranges and habitat information were obtained from the Floras of the region (Hultén, 1968; Khokhryakov, 1985; Tolmatchev and Packer, 1995; Cody, 1996; Barkworth, 2005). Additional habitat information was obtained from the literature (Hanson, 1953; 


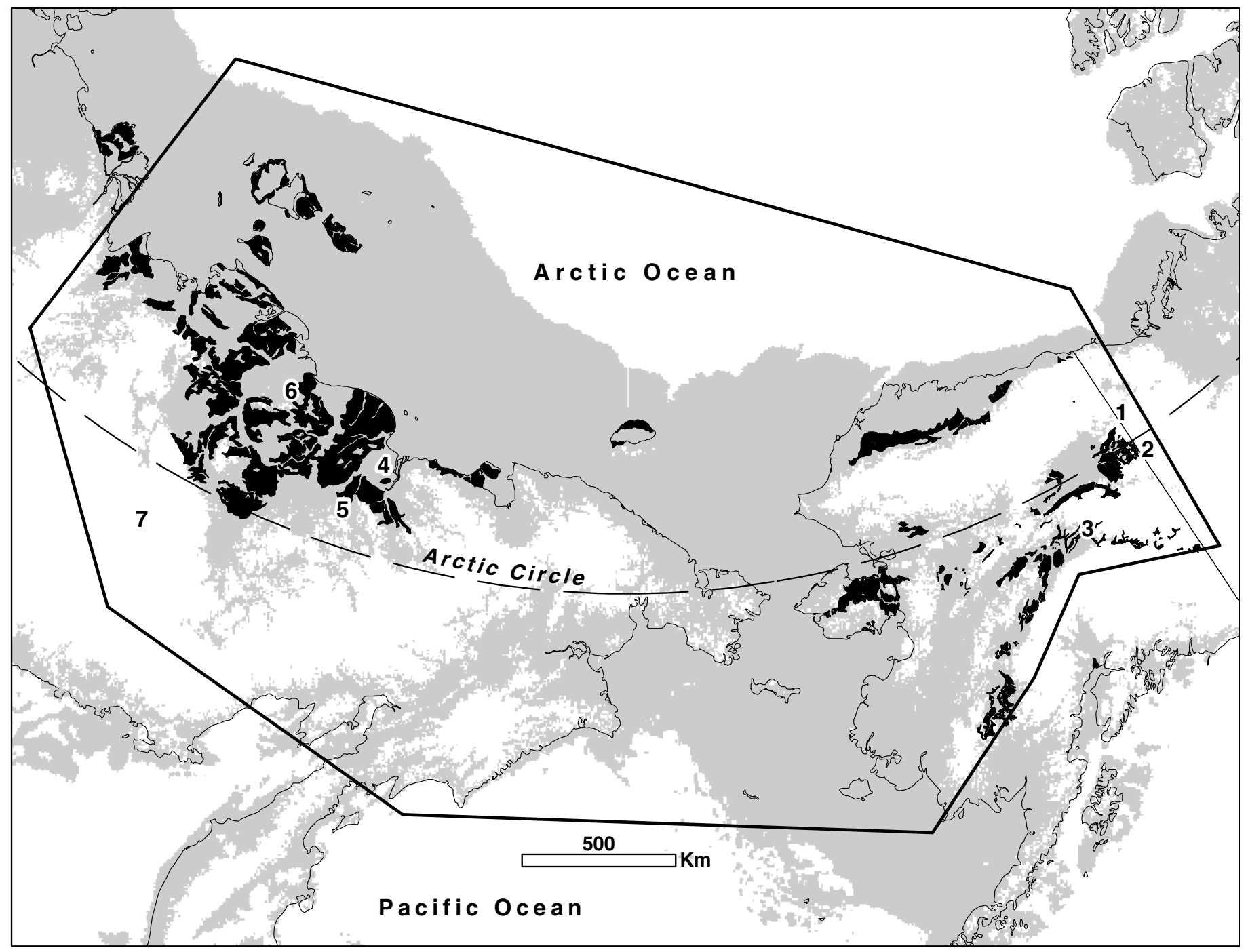

FIG. 1. The study area. Shown in gray are areas between $-100 \mathrm{~m}$ (approximating low sea level during full glacial conditions) and $+300 \mathrm{~m}$ elevation (an arbitrary upper limit to lowlands). These lowlands were largely unglaciated during Pleistocene, except for south coastal Alaska and areas near mountain ranges (Hopkins, 1967). Remnant areas of permanently frozen Pleistocene silty sediments are shown in black (Naumov, 1993 for Asia and Karlstrom et al., 1964 for Alaska). Bathymetry and topography are from NGDC (2004). Numbers are locations of grass macrofossils listed in Table 1.

Churchill, 1955; Spetzman, 1959; Johnson et al., 1966; Walker, 1985; Khokhryakov, 1989; Kozhevnikov, 1989; Walker et al., 1991; Walker and Everett, 1991; Viereck et al., 1992; Walker et al., 2001).

The study area (Fig. 1) was defined as follows. The eastern limit of the Pleistocene Beringian silty lowlands is determined by mountains and the Cordilleran ice sheet. In the west, ice-rich, silty, Pleistocene deposits occur in lowlands throughout northeastern Asia: in Chukotka, the Magadan Oblast, and northern Sakha (Yakutia). As a western boundary for this study, I chose the prominent barrier formed by the Verkhoyansk-Suntar-Khayata Mountains.

Taxonomy of listed species is based on the regional floras cited above, as well as the USDA PLANTS National Database (USDA-NRCS, 2004), Aiken et al. (1996 and onwards), and Czerepanov (1995; maintained online by IOPI, 2004).

\section{RESULTS AND DISCUSSION}

In total, 25 species from 13 grass genera range across the study area on mesic to dry sites (Table 2). All of these species have been reported growing on silty or sandy lowland soils except Festuca lenensis, which has apparently been found in the study area only on rocky slopes. (Of course, some species that are well documented on lowland sites are actually more common today on rocky alpine tundra, e.g., Festuca altaica and Hierochloëalpina.) Most of the listed grasses are high-latitude species of common temperate-zone genera (Festuca, Poa, Bromus, etc.) or, in the case of Arctagrostis, a uniquely highlatitude genus. Evolution of these unique species from temperate-zone, cool-season grasses is not surprising given the large extent (Bigelow et al., 2003) and long history (Matthews, 1974) of tundra and tundra-steppe biomes in the Pleistocene. Many of the grasses have broad, nearly 
TABLE 2. List of most probable lowland grass species in late Pleistocene Beringia: grasses recorded on mesic to dry, finegrained lowland soils and distributed across northwestern North America and northeastern Asia.

\section{Species}

Alopecurus alpinus $\mathrm{Sm}$

Arctagrostis latifolia (R. Br.) Griseb. ${ }^{1}$

Bromus pumpellianus Scribn.

Calamagrostis canadensis (Michx.) P. Beauv. ssp. langsdorfii (Link) Hult. Calamagrostis stricta (Timm) Koeler

Calamagrostis lapponica (Wahlenb.) Hartman

Calamagrostis purpurascens $\mathrm{R}$. Br.

Deschampsia cespitosa (L.) Beauv. ${ }^{2}$

Elymus alaskanus (Scribn. \& Merr.) A. Löve ${ }^{3}$

Elymus macrourus (Turcz.) Tzvelev

Elymus trachycaulus (Link) Gould ex Shinners

Festuca altaica Trin.

Festuca brachyphylla J.A. Schultes

Festuca lenensis Drobow ${ }^{4}$

Festuca rubra L. 5

Hierochloë alpina (Sw.) Roemer \& J.A. Schultes

Hierochlö̈ hirta (Schrank) Borbas ssp. arctica (J. Presl) G Weim.

Hordeum jubatum L.

Koeleria asiatica Domin. ${ }^{6}$

Poa arctica $\mathrm{R}$. Br. ${ }^{7}$

Poa glauca Vahl

Poa pratensis L. ssp. alpigena (Fries ex Blytt) Hiitonen

Poa paucispicula Scribn. \& Merr.

Puccinellia hauptiana (Krecz.) Kitagawa

Trisetum spicatum (L.) Richter

${ }^{1}$ Including the more robust ssp. arundinacea (Trin.) Griseb., which has a range nearly coincident with the study area and which Russian sources regard as a separate species.

${ }^{2}$ Species in the broad sense after Barkworth (2005), including $D$. brevifolia, D. arctica, and D. borealis.

${ }^{3}$ Agropyron boreale (Turcz.) Drobov in my older sources.

${ }^{4}$ Habitats reported to date in the study area are all apparently rocky slopes.

${ }^{5}$ Species in the broad sense after Aiken et al. (2000), including ssp. richardsonii (Hook.) Hultén.

${ }^{6}$ This species has been reported only in the northern half of the study area.

${ }^{7}$ Species in the broad sense after Barkworth (2005), including $P$. malacantha and P. lanata.

circumpolar ranges. These broad ranges suggest that some of the grasses on the tundra steppes of the Beringian region could have ranged across a larger, circumarctic tundrasteppe biome (Guthrie, 2001; Bigelow et al., 2003). A few of the species (Koeleria asiatica, Festuca altaica, and $F$. lenensis) are restricted to northwestern North America and northeastern Asia. Festuca lenensis is the only grass on the list that is common in mid-latitude Asian steppes (Tolmatchev and Packer, 1995).

The diversity of potential Pleistocene lowland grasses is perhaps surprising in view of the overall paucity of grass-dominated vegetation in the study area today. There are multiple species adapted to moist-mesic conditions (Alopecurus alpinus, Arctagrostis latifolia, Calamagrostis canadensis, Deschampsia cespitosa, Poa arctica) and dry

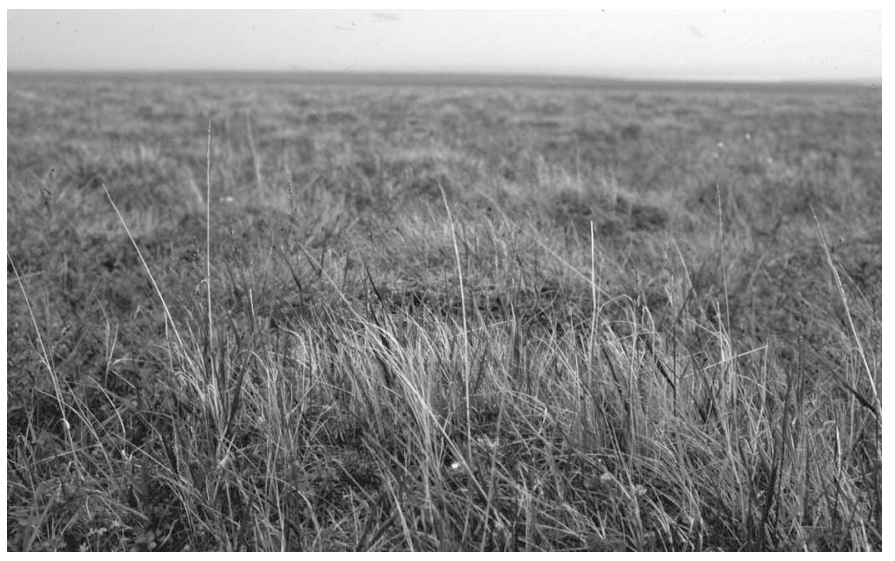

FIG. 2. Grass-rich tundra near the mouth of the Kolyma River $\left(69^{\circ} 28^{\prime} \mathrm{N}\right.$, $161^{\circ} 46^{\prime} \mathrm{E}$ ), in northern Sakha (Yakutia). The prominent grass is Arctagrostis latifolia. This area has silty soils over ice-rich permafrost (Smith et al., 1995) and average annual precipitation of just $20 \mathrm{~cm}$ (Matveev, 1989).

conditions (Calamagrostis purpurascens, Festuca lenensis, Koeleria asiatica, Poa glauca). This span in moisture adaptations suggests that some species would have been available to populate the variety of habitats thought to have been present on the Pleistocene lowlands (Young, 1982; Elias et al., 2000; Bigelow et al., 2003). These habitats would have ranged, for example, from dry windswept ridges or sandy soils to moist depressions and snowbeds, and from drier interior valleys to the more humid vicinity of the Bering Strait proper. The wide range in adaptations of these grasses also suggests that species would have been available to fill a range of niches through the wide variations of the Pleistocene climate, from the cold arid conditions of the full glacial times to moister and milder interstadial conditions verging on those of today (Hopkins, 1982; Elias, 2001).

Arctic plant species with no specialized distancedispersal adaptations have accomplished long-distance dispersal across oceans in the Holocene (Abbott and Brochmann, 2003). Thus it is possible that some of the species in Table 2 were in fact not present in Pleistocene Beringia, and their range today is a Holocene phenomenon. However, the simplest explanation for their diversity and widespread distribution across this large region of mostly unsuitable habitat is that they are relicts from more widespread dry habitats in the past.

It is interesting to note that nearly all the grasses that meet the range and habitat requirements for this study on one side of the Bering Strait also meet it on the other side. The only exceptions are Puccinellia borealis Swallen, which is widespread in Alaska but rare and local in northeastern Asia; Leymus ajanensis (V.N. Vassil.) Tzvelev, widespread in northeast Asia but found in North America only on the Seward Peninsula, Alaska; Festuca auriculata Drobow, widespread in northeastern Asia although predominantly on rocky sites; possibly present in North America (see Aiken et al., 1996 and onwards); and some taxonomically confusing species of genus Poa section Stenopoa Dumortier, discussed below, that have close 
relatives in North America. This pattern confirms that the Bering Land Bridge has served as a migration corridor for grasses adapted to cold and mesic-to-dry conditions, even though its environment was probably less continental than the rest of Beringia (Elias et al., 1997; Guthrie, 2001). Elias et al. (1997) refuted the idea of a continuous Beringian tundra steppe with their strong fossil evidence for mesic shrub-graminoid tundra in the central Bering Land Bridge during the late Pleistocene. However, their data support the role of the Land Bridge as a migration corridor for grasses, because grass pollen was the most abundant type in nearly all of their samples.

The list of proposed Pleistocene Beringian grasses (Table 2) includes a number of robust, productive species that could have provided forage for large herbivores. Alaskan collections of six of these grasses (Arctagrostis latifolia, Bromus pumpellianus, Calamagrostis canadensis, Elymus macrourus, Elymus trachycaulus, and Festuca rubra) have produced forage yields in field trials similar to northern-adapted domestic forage grasses (Klebesadel, 1994). Eriophorum tundra vegetation has been converted into productive hayfields of $A$. latifolia by simply disking, fertilizing with nitrogen, and seeding the grass (A. Schvirst, Magadan Agricultural Institute, Russia, pers. comm. 1990). Similarly, grasses may have been favored over other plants in the Pleistocene by ungulate grazing and trampling (Zimov et al., 1995) and loess deposition (Laxton et al., 1996). Impressive natural stands of A. latifolia grow on silty tundra in northern Sakha (Yakutia, Fig. 2), an area that has been suggested as a reasonably close analog of Pleistocene conditions throughout the larger region (Smith et al., 1995), and which supports free-ranging horses today (Zimov et al., 1995).

\section{Comparison with Macrofossil Evidence}

Most of the grass genera and eight of the species singled out by biogeographical evidence (Table 2) have been identified in the fossil record (Table 1). Reports from the fossil collections repeatedly mention the abundance of $P o a$ and Festuca remains, confirming the importance of these genera on the Pleistocene Beringian plains. The preponderant agreement between the fossil and biogeographical evidence lends support to the notion that Beringian grasses have a Pleistocene history of expansion and contraction from local refugia in response to climate change, expanding when drought improved soil conditions for mesic- to xeric-adapted species, or cold and drought removed competing woody vegetation (see Edwards and Armbruster, 1989; Wesser and Armbruster, 1991), and contracting during warm, moist periods such as the present. Herbivore-mediated removal of competing vegetation and enhancement of nutrient cycling also may have favored grasses in the Pleistocene (Zimov et al., 1995). Evidence for widespread northward expansion of southern steppe grass species into the region during Pleistocene cold/dry periods remains weak.
Given the sparse nature of fossil sites and the difficulty of identifying grass fragments to the species level, failure of paleontologists to confirm many of the species listed in Table 2 should not yet be taken as evidence that they were absent from Pleistocene Beringia. New macrofossil finds continue to turn up new species, and future studies, especially identification of species from DNA preserved in permafrost (Willerslev et al., 2003), may confirm that more of these species were present in Pleistocene Beringia.

The fossil record (Table 1) contains a few species that are not on my list (Table 2). Two of the fossil species, Arctophila fulva (Trin.) Rupr. ex Anderss. and Beckmannia eruciformis (L.) Host, were excluded from my list because they are wetland grasses. All of the remaining fossil species missing from my list were found in deposits of the relatively warm period from about 30000 to 50000 years $\mathrm{BP}$, known as the Kargin interglacial in Russia or the Boutellier Interval in North America (Hopkins, 1982). Two of them, Poa botryoides (Trin. ex Griseb.) Roshev. and $P$. attenuata Trin., are closely related species which, along with their close relative $P$. glauca (which is on my list), are among the many drought-adapted species of Poa section Stenopoa recognized by Russian botanists. In view of the taxonomic difficulties involved here, the find of these two Poa species by Gubin et al. (2003) is best interpreted as confirmation that the drought-tolerant grasses of Poa section Stenopoa, including P. glauca and relatives, were important on the Pleistocene Beringian plains.

The four remaining grasses that have been found as fossils but are missing from Table 2 are more southerly species. Two are highly drought-tolerant grasses, Helictotrichon krylovii (N. Pavl.) Henrard and Agropyron cristatum (L.) Gaertn., which occur today on dry sites in the highly continental, southwestern part of the study area (Yurtsev, 1982). The third is Danthonia, a genus that mainly inhabits moist sites in temperate regions, whose identification from a tiny fragment on the tooth of one bison should be interpreted with caution. If confirmed, it would most likely be Danthonia intermedia Vasey, an amphi-Beringian species that today skirts the study area to the south and east. The fourth is Hordeum brevisubulatum (Trinius) Link, a central Asian montane grass that is rare and probably introduced in the study area today (Khokhryakov, 1985; von Bothmer et al., 1995). These finds suggest northward range expansions of some grasses in continental parts of the study area during the Boutellier Interval/Kargin Interstadial. In parts of northeastern Asia, trees were found north of their present-day limit during at least part of this period, suggesting that conditions were warmer than at present (Solonevich et al., 1977; Ukraintseva, 1981). These relatively mild conditions, which persisted for longer than our present 10000 year warm period, apparently provided better opportunities for some more southerly species to colonize the continental parts of the study area than they have had during the Holocene. The occurrence of these species in Pleistocene interstadial deposits of the southeastern and southwestern parts of the 
study area reminds us that the floras of these areas were probably enriched with species unique to their respective continents in the Pleistocene, as they are today (Swanson, 2003).

\section{Comparison with Steppe Slope Communities}

Islands of steppe habitat rich in grasses, found on dry, steep, south-facing slopes within the taiga of Alaska, the Yukon, and northeastern Asia, have attracted attention as possible analogs of the Pleistocene Beringian landscape (Hanson, 1951; Yurtsev, 1982; Murray et al., 1983; Edwards and Armbruster, 1989; Lloyd et al., 1994; Roland, 1996; Vetter, 2000). Four grasses common in steppes on south slopes in the taiga of the North American part of the study area are on the list of probable Pleistocene lowland grasses (Table 2): Calamagrostis purpurascens, Bromus pumpellianus, Festuca altaica, and Poa glauca. Also in Table 2 are several common grasses of steppe patches on south-facing slopes in the taiga of northeastern Asia: Agropyron boreale (Elymus alaskanus), Calamagrostis purpurascens, and Festuca lenensis (Permyakova, 1973; Khokhryakov and Shatkauskas, 1973; Yurtsev, 1982). The Russian sources also frequently identify Poa botryoides, which is close to Poa glauca, as discussed above. Missing from Table 2 are the common south-slope steppe grasses from the study area with ranges that extend south into midlatitudes: Pseudoroegnaria spicata (Pursh) A. Löve (North America) and Elytrigia jacutorum Nevski (Asia). Also missing is the north-central interior Asian endemic Helictotrichon krylovii.

To understand the relationship between the vegetation of today's steppes on steep, south-facing slopes and the vegetation of the Pleistocene lowlands, it is helpful to note the similarities and differences between their soil environments. Soils on south-facing steppe slopes in the taiga zone of interior Alaska (author's observations) and interior northeastern Asia (Naumov and Andreeva, 1963) are rocky, low in organic matter, and lack permafrost. Thus, they are rather unlike the ice- and organic-rich silty soils of the Pleistocene lowlands. In terms of environment for plant growth, today's steppes on south-facing slopes are probably best as analogs of droughty, infertile sites on the Pleistocene Beringian plains (such as windswept topographic convexities) and of more extensive steppes on south-facing slopes that presumably existed during dry periods in the Pleistocene (Edwards and Armbruster, 1989). Today's steppes on south-facing slopes share two significant environmental constraints with dry, windswept Pleistocene sites: summer drought and the occurrence of very low winter temperatures with little snow cover. Communities from the colder, high-elevation steppe-tundra transitional sites on south-facing slopes (Edwards and Armbruster, 1989; Lloyd et al., 1994) are especially promising as analogs of Pleistocene communities on droughty or shallow soils. South-facing slopes in today's taiga zone are weaker analogs for the more mesic, loessal, nutrient- rich soils of the Pleistocene Beringian plains, which, as discussed in the introduction, we have reason to believe were widespread. The greater overall heat supply (as shown by their lack of permafrost) on south-facing slopes with steppe vegetation in the taiga zone also creates niches for more warmth-demanding, southern species such as $P$. spicata (Lloyd et al., 1994), E. jacutorum, and H. krylovii, for which the Pleistocene Beringian lowlands apparently presented a barrier to migration. Grass-rich communities on pingos in northern Alaska (Walker et al., 1991) often occur on fine-grained soils over permafrost, an environment that is probably closer to what prevailed on the Pleistocene Beringian plains.

\section{CONCLUSION}

Many mesic- to xeric-adapted grasses are widely distributed on refugia across the otherwise largely waterlogged or forested lowland environments of northeastern Asia and northwestern North America. The simplest explanation for the diversity and widespread distribution of these grasses across this large region of mostly unsuitable habitat is that they are relicts of more widespread dry habitats in the Pleistocene. These grasses are mostly highlatitude species of genera that are also widespread in the temperate zone. They probably have had a history of expansion when drought improved site conditions or cold removed competing woody vegetation and contraction during warm, moist periods such as the present. The species chosen by biogeographical criteria are in good agreement with fossil evidence and represent our best guess as to which grasses inhabited the plains of the Beringian region during the Pleistocene and were important forage plants for the large mammal herbivores of that time.

\section{ACKNOWLEDGEMENTS}

Thanks to David Murray, Grant Zazula, Nancy Bigelow, and two anonymous reviewers for valuable comments on the manuscript.

\section{REFERENCES}

ABBOTT, R.J., and BROCHMANN, C. 2003. History and evolution of the Arctic flora: In the footsteps of Eric Hultén. Molecular Ecology 12(2):299-313.

AIKEN, S.G., DALLWITZ, M.J., McJANNET, C.L., and CONSAUL, L.L. 1996 and onwards. Festuca of North America: Descriptions, illustrations, identification, and information retrieval. Version: 19 October 2005. http://delta-intkey.com/ festuca/. Accessed 3 April 2006.

ANDERSON, P.M., and BRUBAKER, L.B. 1994. Vegetation history of northern Alaska: A mapped summary of late-Quaternary pollen data. Quaternary Science Reviews 13:71-92. 
BARKWORTH, M., ed. 2005. Synonymy for the Manual of North American Grasses North of Mexico and Flora North America, Vols. 24 and 25. Logan, Utah: Utah State University. http:// herbarium.usu.edu/GrassManual/default.htm. Accessed 8 April 2005.

BIGELOW, N.H., BRUBAKER, L.B., EDWARDS, M.E., HARRISON, S.P., PRENTICE, I.C., ANDERSON, P.M., ANDREEV, A.A., BARTLEIN, P.J., CHRISTENSEN, T.R., CRAMER, W., KAPLAN, J.O., LOZHKIN, A.V., MATVEYEVA, N.V., MURRAY, D.F., McGUIRE, A.D., RAZZHIVIN, V.Y., RITCHIE, J.C., SMITH, B., WALKER, D.A., GAJEWSKI, K., WOLF, V., HOLMQVIST, B.H., IGARASHI, Y., KREMENETSKII, K., PAUS, A., PISARIC, M.F.J., and VOLKOVA, V.S. 2003. Climate change and Arctic ecosystems: 1. Vegetation changes north of $55^{\circ} \mathrm{N}$ between the last glacial maximum, mid-Holocene, and present. Journal of Geophysical Research 108(D19), 8170, doi:10.1029/ 2002JD002558.

CAVM TEAM. 2003. Circumpolar Arctic vegetation map. Scale 1:7 500 000. Conservation of Arctic Flora and Fauna (CAFF) Map No. 1. Anchorage, Alaska: U.S. Fish and Wildlife Service.

CHURCHILL, E.D. 1955. Phytosociological and environmental characteristics of some plant communities in the Umiat region of Alaska. Ecology 36(4):606-627.

CODY, W.J. 1996. Flora of the Yukon Territory. Ottawa: National Research Council of Canada Press.

COLINVAUX, P.A. 1967. Quaternary vegetation history of Arctic Alaska. In: Hopkins, D.M., ed. The Bering land bridge. Stanford, California: Stanford University. 207-231.

CZEREPANOV, S.K. 1995. Vascular plants of Russia and adjacent states (the former USSR). Cambridge: Cambridge University Press.

EDWARDS, M.E., and ARMBRUSTER, W.S. 1989. A tundrasteppe transition on Kathul Mountain, Alaska, U.S.A. 1989. Arctic and Alpine Research 21(3):296-304.

ELIAS, S.A. 2001. Mutual climatic range reconstructions of seasonal temperatures based on Late Pleistocene fossil beetle assemblages in eastern Beringia. Quaternary Science Reviews 20:77-91.

ELIAS, S.A., SHORT, S.K., and BIRKS, H.H. 1997. Late Wisconsin environments of the Bering land bridge. Palaeogeography, Palaeoclimatology, Palaeocology 136:293-308.

ELIAS, S.A., BERMAN, D., and ALFIMOV, A. 2000. Late Pleistocene beetle faunas of Beringia: Where east met west. Journal of Biogeography 27:1349-1363.

EVERETT, K.R. 1980. Distribution and variability of soils near Atkasook, Alaska. Arctic and Alpine Research 12:433-446.

EVERETT, K.R., and PARKINSON, R.J. 1977. Soil and landform associations, Prudhoe Bay area, Alaska. Arctic and Alpine Research 9(1):1-19.

FRASER, T.A., and BURN, C.R. 1997. On the nature and origin of "muck" deposits in the Klondike area, Yukon Territory. Canadian Journal of Earth Sciences 34:1333-1344.

GOETCHUS, V.G., and BIRKS, H.H. 2001. Full-glacial upland tundra vegetation preserved under tephra in the Beringia National Park, Seward Peninsula, Alaska. Quaternary Science Reviews 20:135-147.
GUBIN, S.V. 1994. Late Pleistocene soil formation on coastal lowlands of northern Yakutia. Eurasion Soil Science 27(5): 19-32. (Translated from Pochvovedenie 8:5-14).

GUBIN, S.V., ZANINA, O.G., MAKSIMOVICH, S.V., KUZ'MINA S.A., and ZAZHIGIN, V.S. 2003. Reconstruction of ice-complex sediments formation conditions from the study of Late Pleistocene rodent burrows. Kriosfera Zemli 7(3): 13-22. (In Russian)

GUTHRIE, R.D. 1990. Frozen fauna of the mammoth steppe: The story of Blue Babe. Chicago, Illinois: University of Chicago.

- 2001. Origin and causes of the mammoth steppe: A story of cloud cover, woolly mammal tooth pits, buckles, and insideout Beringia. Quaternary Science Reviews 20:549-574.

HANSON, H.C. 1951. Characteristics of some grassland, marsh, and other plant communities in western Alaska. Ecological Monographs 21(4):317-378.

- 1953. Vegetation types in northwestern Alaska and comparisons with communities in other Arctic regions. Ecology 34(1): $111-140$.

HÖFLE, C., and PING, C.L. 1996. Properties and soil development of late-Pleistocene paleosols from Seward Peninsula, northwest Alaska. Geoderma 71:219-243.

HÖFLE, C., EDWARDS, M.E., HOPKINS, D.M., MANN, D.H., and PING, C.L. 2000. The full-glacial environment of the northern Seward Peninsula, Alaska, reconstructed from the 21,500-year-old Kitluk paleosol. Quaternary Research 53(2): $143-153$.

HOPKINS, D.M. 1967. The Cenozoic history of Beringia - A synthesis. In: Hopkins, D.M., ed. The Bering land bridge. Stanford, California: Stanford University Press. 451-484.

1982. Aspects of the paleogeography of Beringia during the late Pleistocene. In: Hopkins, D.M., Matthews, J.V., Schweger, C.E., and Young, S.B., eds. Paleoecology of Beringia. New York: Academic Press. 3-28.

HULTÉN, E. 1968. Flora of Alaska and neighboring territories. Stanford, California: Stanford University Press.

IOPI (INTERNATIONAL ORGANIZATION FOR PLANT INFORMATION). 2004. Provisional global plant checklist. http:/ /bgbm3.bgbm.fu-berlin.de/iopi/gpc/. Accessed 8 April 2005.

JOHNSON, A.W., VIERECK, L.A., JOHNSON, R.E., and MELCHIOR, H. 1966. Vegetation and flora. In: Wilmovsky, N.J., ed. Environment of the Cape Thompson region, Alaska. Washington, D.C.: US Atomic Energy Commission. 277-354.

KARLSTROM, T.N.V., COULTER, H.W., FERNALD, A.T., WILLIAMS, J.R., HOPKINS, D.M., PÉWÉ, T.L., DREWES, H., MULLER, E.H., and CONDON, W.H. 1964. Surficial geology of Alaska. Miscellaneous Geologic Investigations Map I-357. Washington, D.C.: US Geological Survey. Scale 1:1584000.

KHOKHRYAKOV, A.P. 1985. Flora Magadanskoy oblasti (Flora of the Magadan Province). Moscow: Nauka. (In Russian) 1989. Analyz flory Kolymskogo nagor'ya (Analysis of the Kolyma Upland flora). Moscow: Nauka. (In Russian)

KHOKHRYAKOV, A.P., and SHATKAUSKAS, A.V. 1973. Steppe flora in the upper Kolyma basin. In: Pochvy i rastitel'nost' merzlotnykh rayonov SSSR (Soils and vegetation of permafrost regions of the USSR). Magadan: DVNTs, AN SSSR. 136-140. (In Russian) 
KLEBESADEL, L.J. 1994. Winterhardiness, forage production, and persistence of introduced and native grasses and legumes in southcentral Alaska. School of Agriculture and Land Resources Management, Agricultural and Forestry Experiment Station, Bulletin 101. Fairbanks, Alaska: University of Alaska.

KOTLER, E., and BURN, C.R. 2000. Cryostratigraphy of the Klondike "muck" deposits, west-central Yukon Territory. Canadian Journal of Earth Sciences 37:849-861.

KOZHEVNIKOV, Yu. P. 1989. Geografiya rastitel'nosti Chukotki (Plant geography of Chukotka). Leningrad: Nauka. (In Russian)

LAXTON, N.F., BURN, C.R., and SMITH, C.A.S. 1996. Productivity of loessal grasslands in the Kluane Lake region, Yukon Territory, and the Beringian "production paradox." Arctic 49(2):129-140.

LLOYD, A.H., ARMBRUSTER, W.S., and EDWARDS, M.E. 1994. Ecology of a steppe-tundra gradient in interior Alaska. Journal of Vegetation Science 5:897-912.

LOZHKIN, A.V., ANDERSON, P.M., EISNER, W.R., RAVAKO, L.G., HOPKINS, D.M., BRUBAKER, L.B., COLINVAUX, P.A., and MILLER, M.C. 1993. Late Quaternary lacustrine pollen records from southwestern Beringia. Quaternary Research 39(3):314-324.

MATTHEWS, J.V. 1974. Quaternary environments at Cape Deceit (Seward Peninsula, Alaska): Evolution of a tundra ecosystem. Geological Society of America Bulletin 85:1353-1384.

MATVEEV, I.A. 1989. Atlas sel'skogo khozyaystva Yakutskoy ASSR (Agricultural atlas of Yakutia ASSR). Moscow: GUGK. (In Russian)

MURRAY, D.F., MURRAY, B.M., YURTSEV, B.A., and HOWENSTEIN, R. 1983. Biogeographic significance of steppe vegetation in Subarctic Alaska. Permafrost: Fourth International Conference, Proceedings, 17-22 July, Fairbanks, Alaska. Washington, D.C.: National Academy of Sciences. 883-888.

NAUMOV, Ye.M. 1993. Pochvennaya karta severo-vostoka Yevrazii (Soil map of northeastern Eurasia). Moscow: GUGK. Scale 1:2 500 000. (In Russian)

- 2004. Soils and soil cover of northeastern Eurasia. In: Kimble, J.M., ed. Cryosols: Permafrost-affected soils. Berlin: Springer-Verlag. 161-183.

NAUMOV, Ye.M., and ANDREEVA, A.A. 1963. Pochvy ostepnennykh sklonov Yansko-Indigirskogo Nagor'ya (Soils of steppe slopes on the Yana-Indigirka Plateau). Pochvovedeniye 1963(3):62-70.

NGDC (NATIONAL GEOPHYSICAL DATA CENTER). 2004. 2-minute gridded global relief data (ETOPO2). Boulder, Colorado: NGDC. http://www.ngdc.noaa.gov/mgg/fliers/ 01mgg04.html. Accessed 28 September 2004.

PERMYAKOVA, A.A. 1973. Fragments of steppe vegetation in the middle Kolyma region. In: Pochvy I rastitel'nosti merzlotnykh rayonov SSSR (Soils and vegetation of permafrost regions in the USSR). Magadan: DVNTs AN SSSR. 141-147. (In Russian)

PÉWÉ, T.L. 1975. Quaternary geology of Alaska. Professional Paper 835. Washington, D.C.: U.S. Geological Survey.

PING C.L., CLARK M.H., and SWANSON D.K. 2004. Cryosols in Alaska. In: Kimble, J.M., ed. Cryosols: Permafrost-affected soils. Berlin: Springer-Verlag. 71-94.
ROLAND, C. 1996. The floristics and community ecology of extrazonal steppe in the Yukon and Kolyma drainages. MS Thesis, University of Alaska, Fairbanks, Alaska. 205 p.

ROMANOVSKII, N.N., HUBBERTON, H.-W., GAVRILOV A.V., TUMSKOY, V.E., and KHOLODOV, A.L. 2004. Permafrost of the east Siberian Arctic shelf and coastal lowlands. Quaternary Science Reviews 23:1359-1369.

SANBORN, P., SMITH, C.A.S., FROESE, D., ZAZULA, D.G., and WESTGATE, J.A. In press. Full-glacial paleosols in perennially frozen loess sequences, Klondike goldfields, Yukon Territory, Canada. Quaternary Research.

SCHIRRMEISTER, L., SIEGERT, C., KUZNETSOVA, T., KUZMINA, S., ANDREEV, A., KIENAST, F., MEYER, H., and BOBROV, A. 2002. Paleoenvironmental and paleoclimatic records from permafrost deposits in the Arctic region of northern Siberia. Quaternary International 89:97-118.

SMITH, C.A.S., SWANSON, D.K., MOORE, J.P., AHRENS, R.J., BOCKHEIM, J.G., KIMBLE, J.M., MAZHITOVA, G.G., PING, C.L., and TARNOCAI, C. 1995. A description and classification of soils and landscapes of the lower Kolyma River, northeastern Russia. Polar Geography and Geology 19(2):107-126.

SOLONEVICH, N.G., and VIKHIREVA-VASILKOVA, V.V. 1977. Plant remains in the contents of the gastrointestinal tract of the Selerikan fossil horse (Yakutia). In: Skarlato, O.A., ed. Fauna i flora antropogena severo-vostoka Sibiri (The Anthropogene fauna and flora of northeastern Siberia). Leningrad: Nauka, Trudy Zoologicheskogo Instituta, AN SSSR, T. 63. 203-217. (In Russian).

SOLONEVICH, N.T., TIKHOMIROV, B.A., and UKRAINTSEVA, V.V. 1977. Preliminary results from the study of plant remains from the gastrointestinal tract of the Shandrin mammoth (Yakutia). In: Skarlato, O.A., ed. Fauna i flora antropogena severo-vostoka Sibiri (The Anthropogene fauna and flora of northeastern Siberia). Leningrad: Nauka, Trudy Zoologicheskogo Instituta, AN SSSR, T. 63. 277-280. (In Russian)

SPETZMAN, L.A. 1959. Vegetation of the Arctic slope of Alaska. Professional Paper 302-B. Washington, D.C.: U.S. Geological Survey.

SWANSON, D.K. 2003. A comparison of taiga flora in northeastern Russia and Alaska/Yukon. Journal of Biogeography 30:1109-1121.

TEDROW, J.F.C., and HILL, D.E. 1955. Arctic Brown soil. Soil Science 80:265-275.

TOLMATCHEV, A.L., and PACKER, J.G., eds. 1995. Flora of the Russian Arctic. Vol. I. Translated by G.C.D. Griffiths. Edmonton: University of Alberta.

TOMIRDIARO, S.V. 1980. Lessovo-ledovaya formatsiya Vostochnoy Sibiri v pozdnem pleystotsene (Ice-loess formation of eastern Siberia in the Late Pleistocene). Moscow: Nauka. (In Russian)

TOMIRDIARO, S.V., and CHERNENKIY, B.I. 1987. Kriogennoeolovyye otlozheniya vostochnoy arktiki i subarktiki (Cryogeniceolian sediments of the eastern Arctic and Subarctic. Moscow: Nauka. (In Russian) 
UKRAINTSEVA, V.V. 1981. Vegetation of warm late Pleistocene intervals and the extinction of some large herbivorous mammals. Polar Geography and Geology 4:189-203.

USDA-NRCS (U.S. DEPARTMENT OF AGRICULTURE, NATURAL RESOURCES CONSERVATION SERVICE). 2004. The PLANTS database, version 3.5. Baton Rouge, Louisiana: National Plant Data Center. http://plants.usda.gov. Accessed 8 April 2005.

VETTER, M.A. 2000. Grasslands of the Aishihik-Sekulmun Lakes areas, Yukon Territory, Canada. Arctic 53(2):165-173.

VIERECK, L.A., DYRNESS, C.T., BATTEN A.R., and WENZLICK, K.J. 1992. The Alaska vegetation classification. General Technical Report PNW-GTR-286. Portland, Oregon: U.S. Department of Agriculture, Forest Service, Pacific Northwest Research Station. 278 p.

VONBOTHMER, R., JACOBSEN, N., BADEN, C., JØRGENSEN, R.B., and LINDE-LAURSEN, I. 1995. An ecogeographical study of the genus Hordeum. 2nd ed. Systematic and Ecogeographic Studies on Crop Genepools 7. Rome: International Plant Genetic Resources Institute. http://www.ipgri.cgiar.org/ publications/HTMLPublications/271. Accessed 7 April 2005.

WALKER, D.A. 1985. Vegetation and environmental gradients of the Prudhoe Bay region, Alaska. Report 85-14. Hanover, New Hampshire: U.S. Army Corps of Engineers, Cold Regions Research and Engineering Laboratory.

WALKER, D.A., BOCKHEIM, J.G., CHAPIN, F.S., III, EUGSTER, W., NELSON, F.E., and PING, C.L. 2001. Calcium-rich tundra, wildlife, and the "Mammoth Steppe." Quaternary Science Reviews 20:149-163.

WALKER, M.D., and EVERETT, K.R. 1991. Loess ecosystems of northern Alaska: Regional gradient and toposequence at Prudhoe Bay. Ecological Monographs 61(4):437-464.

WALKER, M.D., WALKER, D.A., EVERETT, K.R., and SHORT, S.K. 1991. Steppe vegetation on south-facing slopes of pingos, central Arctic Coastal Plain, Alaska, USA. Arctic and Alpine Research 23(2):170-188.

WESSER, S.D., and ARMBRUSTER, W.S. 1991. Species distribution controls across a forest-steppe transition: A causal model and experimental test. Ecological Monographs 61(3): $323-342$.

WILLERSLEV, E., HANSEN, A.J., BINLADEN, J., BRAND, T.B., GILBERT, T.P., SHAPIRO, B., BUNCE, M., WIUF, C., GILICHINSKY, D.A., and COOPER, A. 2003. Diverse plant and animal genetic records from Holocene and Pleistocene sediments. Science 300:791-795.

YOUNG, S.B. 1982. The vegetation of land-bridge Beringia. In: Hopkins, D.M., Matthews, J.V., Schweger, C.E., and Young, S.B., eds. Paleoecology of Beringia. New York: Academic Press. 179-191.

YURTSEV, B.A. 1982. Relics of the xerophyte vegetation of Beringia in northeastern Asia. In: Hopkins, D.M., Matthews, J.V., Schweger, C.E., and Young, S.B., eds. Paleoecology of Beringia. New York: Academic Press. 157-177.

ZAZULA, G.D. 2002. Full-glacial macrofossils, paleoecology and stratigraphy of the Bluefish exposure, northern Yukon. M.A. Thesis, University of Alberta, Edmonton.

ZAZULA, G.D., FROESE, D.G., SCHWEGER, C.E., MATHEWES, R.W., ALWYNNE B.B., TELKA, A.M., HARINGTON C.R., and WESTGATE J.A. 2003a. Ice-age steppe vegetation in east Beringia. Nature 423:603.

ZAZULA, G.D., FROESE, D.G., TELKA, A.M., MATHEWES, R.W., and WESTGATE J.A. 2003b. Plants, bugs, and a giant mammoth tusk: Paleoecology of Last Chance Creek, Yukon Territory. In: Edmond, D.S., and Lewis, L.L. eds. Yukon exploration and geology 2002. Whitehorse, Yukon: Exploration and Geological Services Division, Yukon Region, Indian and Northern Affairs. 251-258.

ZAZULA, G.D., FROESE, D.G., WESTGATE, J.A., LA FARGE, C., and MATHEWES, R.W. 2005. Paleoecology of Beringian "packrat" middens from central Yukon Territory, Canada. Quaternary Research 63:189-198.

ZIMOV, S.A., CHUPRYNIN, V.I., ORESHKO, A.P., CHAPIN, F.S., III, REYNOLDS, J.F., and CHAPIN, M.C. 1995. Steppetundra transition: A herbivore-driven biome shift at the end of the Pleistocene. American Naturalist 146:765-794. 